\title{
Soil Physical and Physico-chemical Variability Induced by Atriplex nummularia
}

\section{MUNNA L. SHARMA}

Highlight: Spatial variability in two soils supporting 10-year old stands of saltbush (Atriplex nummularia) was examined by evaluating various soil physical and physicochemical properties under and between the plants. The differences in soil properties between these two positions were mostly significant for the surface layer $(0-7.5 \mathrm{~cm})$ but only in a few cases for the 7.5-15 cm layer. No differences were observed below this depth.

Presence of A. nummularia resulted in increased electrolyte concentration, higher sodium adsorption ratio, and higher levels of exchangeable sodium and organic matter in the surface soil. Standard laboratory measurements showed that these physicochemical changes induced a significant deterioration in the structure of the surface soil under the plants as indicated by reduced aggregate stability, poorer drainage, and lowered hydraulic conductivity. Field studies suggested that the bulk density of the surface soil was reduced under the plants but that water penetration and storage in the profile after rains remained unaffected. Probable reasons for the se effects are discussed.

The presence of some arid plants can significantly affect soil properties and thus may cause spatial variability in vege-

At the time of the research, the author was research scientist, CSIRO Division of Plant Industry, Riverina Laboratory, Deniliquin, N.S.W., Australia. At present he is senior research scientist, CSIRO Rangelands Research Unit, Riverina Laboratory, Deniliquin, N.S.W., Australia.

The report is a contribution of CSIRO Division of Plant Industry. The author wishes to thank Mr. J. Tunny for technical assistance in physical measurements, Mr. D. J. Tongway for chemical analysis, and Mr. P. A. Mills for preparing the graphs.

Manuscript received December 1, 1972. tation distribution and plant growth within the community. In such cases, quantitative evaluation of soil properties with respect to spatial variability is essential for a better understanding and management of the ecosystems.

Increased soil salinity and $\mathrm{pH}$ under the plants compared to between the plants of various species of Atriplex have been reportcd previously (Robcrts, 1950; Fireman and Hayward, 1952; Jessup, 1969). These salinity increases may be associated with an increase in exchangeable sodium (Roberts, 1950; Fireman and
Hayward, 1952), which may affect soil physical properties. However, none of the earlier studies has dealt with quantitativc data on soil physical properties. In a recent paper, Sharma and Tongway (1973) reported soil salinity distribution within communities of two regularly spaced saltbush spccies, Atriplex nummularia and $A$. vesicaria. It was demonstrated that both saltbush species induced significantly higher salinity in the $0-15-\mathrm{cm}$ soil horizon beneath the bush canopies compared to between the bushes, and also that $A$. nummularia induced significantly higher salinity than A. vesicaria. This paper reports on the spatial variability in some soil physical and physico-chemical properties as induced by $A$. nummularia on two soil types. The physico-chemical properties investigated were exchangeable and soluble cations; the physical properties were water penetration and storage, structural stability, hydraulic conductivity, and water retention.

\section{Area and Methods}

The experimental site was the one 
used by Sharma and Tongway (1973) and is located at the Falkiner Memorial Field Station, about $24 \mathrm{~km}$ north of Deniliquin in southwest New South Wales. The climate of the area is semiarid continental with an average annual precipitation of $380 \mathrm{~mm}$ and potential evaporation of $1,550 \mathrm{~mm}$. Although rainfall is evenly distributed, the effective precipitation is received mainly during winter.

The experiments were carried out on plantations of $A$. nummularia that had been established on two soil types, Billabong and Rivcrina clay, about 10 years earlier. The average distance between $A$. nummularia plants was $3 \mathrm{~m}$, and the average height and diameter of plants were $1.3 \pm 0.2 \mathrm{~m}$ and $1.2 \pm 0.5 \mathrm{~m}$, respectively. Intervening vegetation was predominantly the grasses Danthonia caespitosa and Stipa variabilis.

The soils used are members of the grey brown and red clays (Stace et al., 1968) on which various saltbush communities occur extensively on the Riverine Plain of southwest New South Wales. The soils are sodic and have alkaline reaction. They have a surface of medium texture, the thickness of which is $5-7 \mathrm{~cm}$ for Billabong clay and $1-2 \mathrm{~cm}$ for Riverina clay. Crystalline gypsum occurs in both soil profiles at a depth of $30-45 \mathrm{~cm}$, and a mixture of gypsum and calcium carbonate occurs below this depth. The mineralogy of both soils is predominantly Kaolinite and Illite with some fraction of randomly interstratified material. Riverina clay exhibits more shrinking and swelling properties than Billabong clay.

In February, 1971, three replicates of five paired soil core $(3.3-\mathrm{cm}$ diameter) samples were collected from two positions, i.e. under the plants $(U)$ and between the plants $(B)$ of $A$. nummularia on both soils. The samples were separated into profile depths, $0-7.5,7.5-15$,
15-30, 30-45, and 45-60 cm, and bulked separately for each replicate at the specificd depth for the two positions. After air drying, the samples were gently crushed and passed through a $2-\mathrm{mm}$ sieve and used for various physical and physico-chemical analyses.

\section{Physico-chemical Analysis}

The exchangeable cations, $\mathrm{Na}^{+}, \mathrm{K}^{+}$, $\mathrm{Mg}^{++}$, and $\mathrm{Ca}^{++}$, were extracted according to the suggested technique of Tucker (1971); soluble cations were extracted according to the method described by U. S. Salinity Laboratory Staff (1954). These were determined by atomic absorption spectroscopy. Organic carbon was determined by the combustion method of Piper (1950).

\section{Physical Analysis}

\section{Laboratory Measurements}

Water desorption characteristics of $<$ 2-mm soil samples were obtained by using tension plates or pressure membrane apparatus, depending on the magnitude of the water potential.

Twenty-five grams of 1-2-mm air dry soil aggregates were flood wetted, followed by end-over-end shaking in distilled water at $30 \mathrm{rpm}$ for 15 minutes. After a suitable settling time, aggregates $>50$ um were determined using a plummet balance (Marshall, 1956). Aggregate stability was expressed as percentage of $>50$-um size aggregates.

The hydraulic conductivity of uniformly packed 1-2-mm air dry aggregates was measured as a function of time by the method previously described by Sharma (1971). The rate of decrease in hydraulic conductivity with time was taken as an index of structural breakdown, while the value of hydraulic conductivity at the end of 24 hours was taken as a comparative measure of structural stability and water movement.

All laboratory measurements were made in a constant-temperature room maintained at $20 \pm 1^{\circ} \mathrm{C}$.

\section{Field measurements}

On eight occasions, the bulk density of soil down the profile was determined from five core samples of $4.80-\mathrm{cm}$ diameter, collected by using thin walled $(0.165 \mathrm{~cm})$ sampling tubes. Differences in water penetration and storage in the profile between and under the plants were evaluated by measuring soil water in situ with a neutron probe before and after heavy summer rains. The after-rain measurements were made as soon as possible following rainfall (within 48 hours) in order to minimize the effect of water loss by vegetation. Additional checks on water penetration and storage in the profile were made on several occasions by determining gravimetric moisture of soil samples collected before and after rains.

\section{Results \\ Physico-chemical Properties}

Mean values of soluble cations, $\mathrm{Na}^{+}$, $\mathrm{K}^{+}, \mathrm{Mg}^{++}$, and $\mathrm{Ca}^{++}$measured at several depths down to $45 \mathrm{~cm}$ in the profiles of Billabong and Riverina clay from two positions, under $(U)$ and between $(B)$ the plants of $A$. nummularia, are presented in Table 1 . In the surface layer $\left(0^{-} 7.5 \mathrm{~cm}\right)$ there was a significantly higher level of all cations at $U$ compared to $B$ position in both soils. Similarly, there were more soluble cations at $U$ position in the $7.5-15-\mathrm{cm}$ layer, but the differences for all the cations were not significant. There was no systematic trend at the lower depths. The sodium adsorption ratios

Table 1. Soluble cations and sodium adsorption ratios in saturation extracts of Billabong and Riverina clay from between (B) and under (U) the plants of Atriplex nummularia.

\begin{tabular}{|c|c|c|c|c|c|c|c|c|c|c|c|}
\hline \multirow[b]{3}{*}{ depth $(\mathrm{cm})$} & \multirow{3}{*}{$\begin{array}{l}\text { Sampling } \\
\text { position }\end{array}$} & \multicolumn{5}{|c|}{ Billabong clay } & \multicolumn{5}{|c|}{ Riverina clay } \\
\hline & & \multicolumn{4}{|c|}{ Soluble cations (meq/1) } & \multirow[b]{2}{*}{$\operatorname{SAR}^{\dagger}$} & \multicolumn{4}{|c|}{ Soluble cations (meq/1) } & \multirow[b]{2}{*}{$\operatorname{SAR}^{\dagger}$} \\
\hline & & $\mathrm{Na}^{+}$ & $\mathrm{K}^{+}$ & $\mathrm{Ca}^{++}$ & $\mathrm{Mg}^{++}$ & & $\mathrm{Na}^{+}$ & $\mathrm{K}^{+}$ & $\mathrm{Ca}^{++}$ & $\mathrm{Mg}^{++}$ & \\
\hline $0-7.5$ & B & $9.84 * *$ & $0.54 *$ & $3.27 *$ & $4.58 *$ & $4.97 *$ & $6.20^{*}$ & $0.33 *$ & $2.38 * *$ & $2.44 * *$ & $3.99 *$ \\
\hline & $\mathbf{U}$ & $22.71 * *$ & $0.72 *$ & $7.55^{*}$ & $13.55^{*}$ & $6.99 *$ & $18.96^{*}$ & $0.84 *$ & $5.52 * *$ & $10.08 * *$ & $6.79^{*}$ \\
\hline $7.5-15$ & $\begin{array}{l}\text { B } \\
\mathbf{U}\end{array}$ & $\begin{array}{l}19.53 \\
27.23\end{array}$ & $\begin{array}{l}0.22 \\
0.25\end{array}$ & $\begin{array}{l}3.89^{*} \\
8.51^{*}\end{array}$ & $\begin{array}{r}5.98^{* *} \\
16.54^{* *}\end{array}$ & $\begin{array}{l}8.79 \\
7.69\end{array}$ & $\begin{array}{r}8.65^{*} \\
15.25^{*}\end{array}$ & $\begin{array}{l}0.17 \\
0.24\end{array}$ & $\begin{array}{l}2.30^{*} \\
5.01^{*}\end{array}$ & $\begin{array}{l}2.17^{*} \\
7.37^{*}\end{array}$ & $\begin{array}{l}5.79 \\
6.13\end{array}$ \\
\hline $15-30$ & $\begin{array}{l}\text { B } \\
\text { U }\end{array}$ & $\begin{array}{l}50.40 \\
47.31\end{array}$ & $\begin{array}{l}0.32 \\
0.33\end{array}$ & $\begin{array}{l}5.24 \\
8.00\end{array}$ & $\begin{array}{l}12.09 \\
17.75\end{array}$ & $\begin{array}{l}17.13 \\
13.19\end{array}$ & $\begin{array}{l}23.02 \\
30.01\end{array}$ & $\begin{array}{l}0.20 \\
0.21\end{array}$ & $\begin{array}{l}2.70 \\
3.21\end{array}$ & $\begin{array}{l}4.32 \\
5.16\end{array}$ & $\begin{array}{l}12.29 \\
14.67\end{array}$ \\
\hline $30-45$ & $\begin{array}{l}\text { B } \\
\text { U }\end{array}$ & $\begin{array}{l}80.36 \\
71.80\end{array}$ & $\begin{array}{l}0.32 \\
0.38\end{array}$ & $\begin{array}{l}8.85 \\
6.07\end{array}$ & $\begin{array}{l}17.21 \\
15.03\end{array}$ & $\begin{array}{l}22.27 \\
22.11\end{array}$ & $\begin{array}{l}45.10 \\
41.80\end{array}$ & $\begin{array}{l}0.27 \\
0.25\end{array}$ & $\begin{array}{l}5.05 \\
4.97\end{array}$ & $\begin{array}{l}8.95 \\
9.37\end{array}$ & $\begin{array}{l}17.04 \\
15.61\end{array}$ \\
\hline
\end{tabular}

\footnotetext{
* Difference between $U$ and $B$ positions at the specified depth significant $(P<0.05)$.
}

**Difference between $U$ and $B$ positions at the specified depth highly significant $(P<0.01)$.

+ Sodium adsorption ratio $=$ $\sqrt{\frac{\mathrm{Ca}^{++}+\mathrm{Mg}^{++}}{2}}$ 
Table 2. Exchangeable cations of Billabong and Riverina clay from between (B) and under (U) the plants of Atriplex nummularia.

\begin{tabular}{|c|c|c|c|c|c|c|c|c|c|c|c|}
\hline \multirow{2}{*}{$\begin{array}{c}\text { Profile } \\
\text { depth }(\mathrm{cm})\end{array}$} & \multirow{2}{*}{$\begin{array}{l}\text { Sampling } \\
\text { position }\end{array}$} & \multicolumn{5}{|c|}{$\begin{array}{l}\text { Billabong clay } \\
\text { (meq/100g soil) }\end{array}$} & \multicolumn{5}{|c|}{$\begin{array}{l}\text { Riverina clay } \\
\text { (meq/100g soil) }\end{array}$} \\
\hline & & $\mathrm{Na}^{+}$ & $\mathrm{K}^{+}$ & $\mathrm{Ca}^{++}$ & $\mathrm{Mg}^{++}$ & $\mathrm{ESP}^{\dagger}$ & $\mathrm{Na}^{+}$ & $\mathrm{K}^{+}$ & $\mathrm{Ca}^{++}$ & $\mathrm{Mg}^{++}$ & $\operatorname{ESP}^{\dagger}$ \\
\hline $0-7.5$ & $\begin{array}{l}\text { B } \\
\text { U }\end{array}$ & $\begin{array}{l}2.33 * * \\
3.63 * *\end{array}$ & $\begin{array}{l}0.89^{*} \\
1.69^{*}\end{array}$ & $\begin{array}{l}7.83 \\
8.01\end{array}$ & $\begin{array}{l}6.86^{*} \\
9.86\end{array}$ & $\begin{array}{l}13.00 * * \\
15.65 * *\end{array}$ & $\begin{array}{l}2.86 * * \\
3.80^{* *}\end{array}$ & $\begin{array}{l}1.70^{*} \\
2.43^{*}\end{array}$ & $\begin{array}{l}9.36 \\
7.46\end{array}$ & $\begin{array}{r}9.83^{*} \\
11.13^{*}\end{array}$ & $\begin{array}{l}12.04 * * \\
15.31 * *\end{array}$ \\
\hline $7.5-15$ & $\begin{array}{l}\mathrm{B} \\
\mathrm{U}\end{array}$ & $\begin{array}{l}4.50^{*} \\
5.20^{*}\end{array}$ & $\begin{array}{l}0.98 \\
1.06\end{array}$ & $\begin{array}{r}10.10 \\
9.86\end{array}$ & $\begin{array}{l}13.30 \\
13.26\end{array}$ & $\begin{array}{l}15.58^{*} \\
17.70^{*}\end{array}$ & $\begin{array}{l}4.10 \\
5.33\end{array}$ & $\begin{array}{l}1.36 \\
1.43\end{array}$ & $\begin{array}{r}10.43 \\
9.66\end{array}$ & $\begin{array}{l}13.83 \\
12.16\end{array}$ & $\begin{array}{l}13.79^{*} \\
18.65^{*}\end{array}$ \\
\hline $15-30$ & $\begin{array}{l}\mathrm{B} \\
\mathrm{U}\end{array}$ & $\begin{array}{l}5.70 \\
6.40\end{array}$ & $\begin{array}{l}0.81 \\
0.90\end{array}$ & $\begin{array}{l}10.83 \\
10.56\end{array}$ & $\begin{array}{l}15.50 \\
15.03\end{array}$ & $\begin{array}{l}17.36 \\
19.46\end{array}$ & $\begin{array}{l}5.40 \\
5.63\end{array}$ & $\begin{array}{l}1.20 \\
1.20\end{array}$ & $\begin{array}{l}10.60 \\
10.73\end{array}$ & $\begin{array}{l}14.06 \\
14.06\end{array}$ & $\begin{array}{l}17.27 \\
17.81\end{array}$ \\
\hline $30-45$ & $\begin{array}{l}\text { B } \\
\mathrm{U}\end{array}$ & $\begin{array}{l}6.86 \\
6.76\end{array}$ & $\begin{array}{l}0.94 \\
0.89\end{array}$ & $\begin{array}{l}9.20 \\
9.93\end{array}$ & $\begin{array}{l}14.50 \\
15.71\end{array}$ & $\begin{array}{l}21.78 \\
20.31\end{array}$ & $\begin{array}{l}7.23 \\
6.43\end{array}$ & $\begin{array}{l}1.13 \\
1.16\end{array}$ & $\begin{array}{l}10.16 \\
10.53\end{array}$ & $\begin{array}{l}14.00 \\
14.36\end{array}$ & $\begin{array}{l}22.23 \\
19.79\end{array}$ \\
\hline
\end{tabular}

* Difference between $U$ and $B$ positions at the specified depth significant $(P<0.05)$.

**Difference between $U$ and $B$ positions at the specified depth highly significant $(P<0.01)$.

$\dagger$ Exchangeable sodium percentage.

(SAR) were significantly higher at $U$ position but only for the surface layer.

Similar data on exchangeable cations presented in Table 2 indicate that for the surface layer, exchangeable $\mathrm{Na}^{+}, \mathrm{K}^{+}$, and $\mathrm{Mg}^{++}$were significantly higher at $U$ compared to $B$ position. However, at 7.5-15 cm depth, only exchangeable $\mathrm{Na}^{+}$was significantly higher. The differences in exchangeable sodium percentage (ESP) between $U$ and $B$ positions were highly significant $(P<0.01)$ for the surface layer and significant $(P<0.05)$ for the subsequent layer. Saltbush plants did not affect the relative proportions of exchangeable cations below $15 \mathrm{~cm}$.

Mean organic carbon contents of soil samples, presented in Table 3, show that in both soils the organic matter was significantly higher under than between the plants, but only for the surface layer.

Table 3. Percent organic carbon of Billabong and Riverina clay from under $(U)$ and between (B) the plants of Atriplex nummularia.

\begin{tabular}{cccccc}
\hline \hline \multirow{2}{*}{$\begin{array}{c}\text { Depth } \\
\text { (cm) }\end{array}$} & \multicolumn{2}{c}{ Billabong clay } & & \multicolumn{2}{c}{ Riverina clay } \\
\cline { 2 - 3 } \cline { 5 - 6 } & B & U & & B & U \\
\hline $0-7.5$ & $0.88^{* *}$ & $1.02^{* *}$ & & $0.96^{*}$ & $1.06^{*}$ \\
7.515 & 0.73 & 0.77 & & 0.67 & 0.65 \\
$15-30$ & 0.54 & 0.54 & & 0.54 & 0.54 \\
\hline
\end{tabular}

* Differences between $U$ and $B$ positions significant $(P<0.05)$.

* *Differences between $U$ and $B$ positions highly significant $(P<0.01)$.

\section{Physical Properties}

The mean water desorption curves of $<2-\mathrm{mm}$ soil samples of $0-7.5-\mathrm{cm}$ and 7.5-15-cm depths for between and under the plant positions are presented in Figure 1 . In both soils, surface soil from $U$ compared to $B$ position held significantly more water in the whole watcr potential range. No such trends were observed for the 7.5-15-cm layer of Riverina clay.
The mean aggregate stability of soil samples from $U$ and $B$ positions is presented as a function of profile depth in Figure 2. For both soils, the aggregate stability was significantly higher at $B$ compared to $U$ positions for the $0-7.5-\mathrm{cm}$ depth, but the differences for 7.5-15-cm were significant only for Billabong clay. The aggregate stability appeared to be higher for $U$ positions at lower depths, but these differences were not significant.

Geometric means of hydraulic conductivity of 1-2-mm aggregates of both soils from two depths are plotted as a function of time in Figure 3. It is clear that hydraulic conductivity of $0-7.5-\mathrm{cm}$ samples from $U$ position decreased at a much faster rate than those from $B$ position and attained a significantly lower value for both soils. A similar trend existed for the 7.5-15-cm of Billabong clay, but the differences were not significant. The hydraulic conductivities of lower depths, although not presented here, were not different for the two positions.

The measured mean bulk densities of soil in the profile of Billabong clay for the depths, $0-7.5,7.5-15,15-30$, and $30-45 \mathrm{~cm}$ were, respectively, $1.45,1.52$, 1.58 , and $1.63 \mathrm{~g} / \mathrm{cm}^{3}$ from the $U$ position and $1.53,1.57,1.60$, and $1.63 \mathrm{~g} / \mathrm{cm}^{3}$ for the $B$ position. Although in general the bulk densities were lower at $U$ compared to $B$ position down to $30-\mathrm{cm}$ depth, differences between the two positions were significant $(P<0.05)$ only for the surface $(0-7.5 \mathrm{~cm})$ layer.

Soil water profiles of Billabong clay obtained by a neutron probe before and after three summer rains (total falls of $3.2,6.9$ and $4.1 \mathrm{~cm}$, respectively) are presented in Figure 4. These profiles

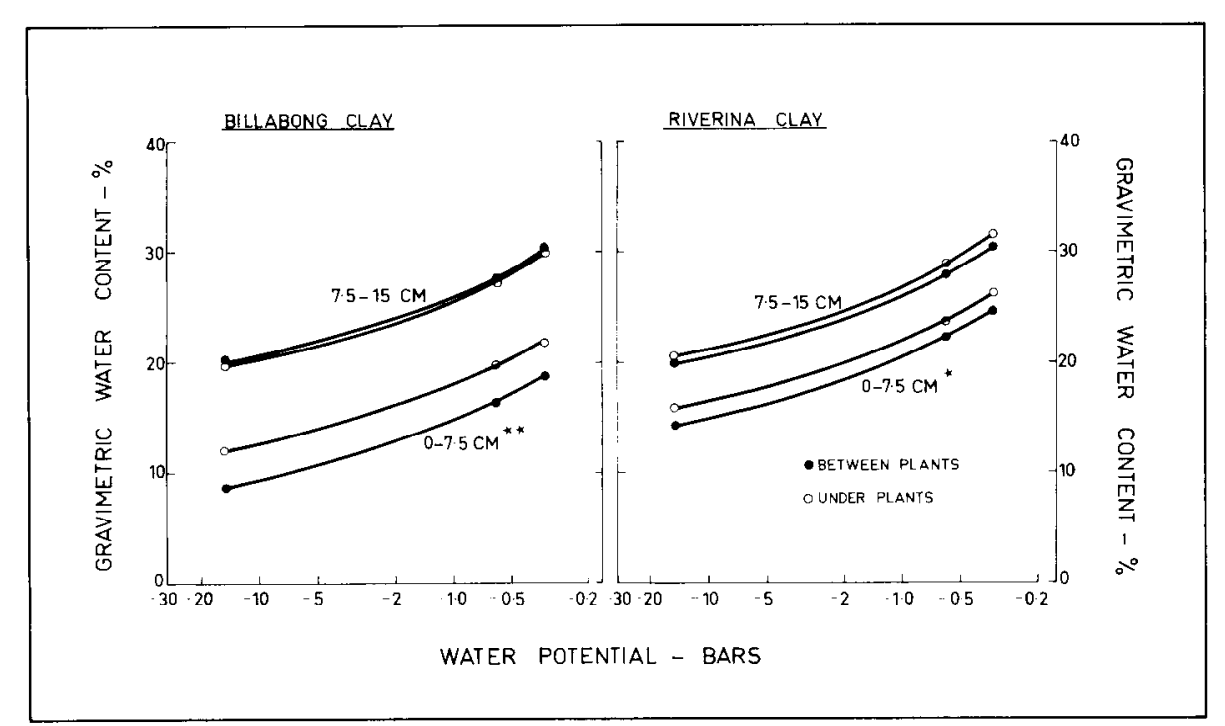

Fig. 1. Mean soil water desorption curves of Billabong and Riverina clay at two depths from between and under the plants of Atriplex nummularia. The statistical significance of difference in water content (iso-water potential level) for the specified depth is indicated by $*(\mathrm{P}<0.05)$ or ** $(\mathrm{P}<0.01)$. 


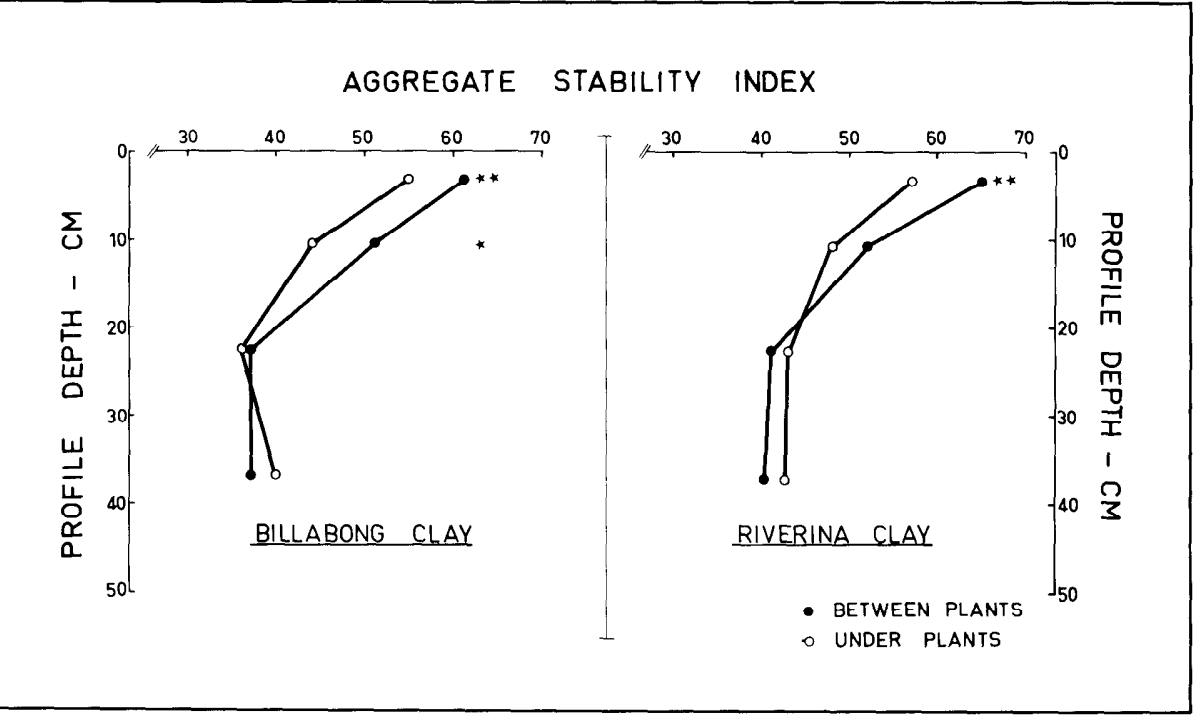

Fig. 2. Mean aggregate stability as a function of profile depth for Billabong and Riverina clay from between and under the plants of Atriplex nummularia. The statistical significance of difference in aggregate stability for the specified depth is indicated by $*(\mathrm{P}<0.05)$ or $* *(\mathrm{P}<0.01)$.
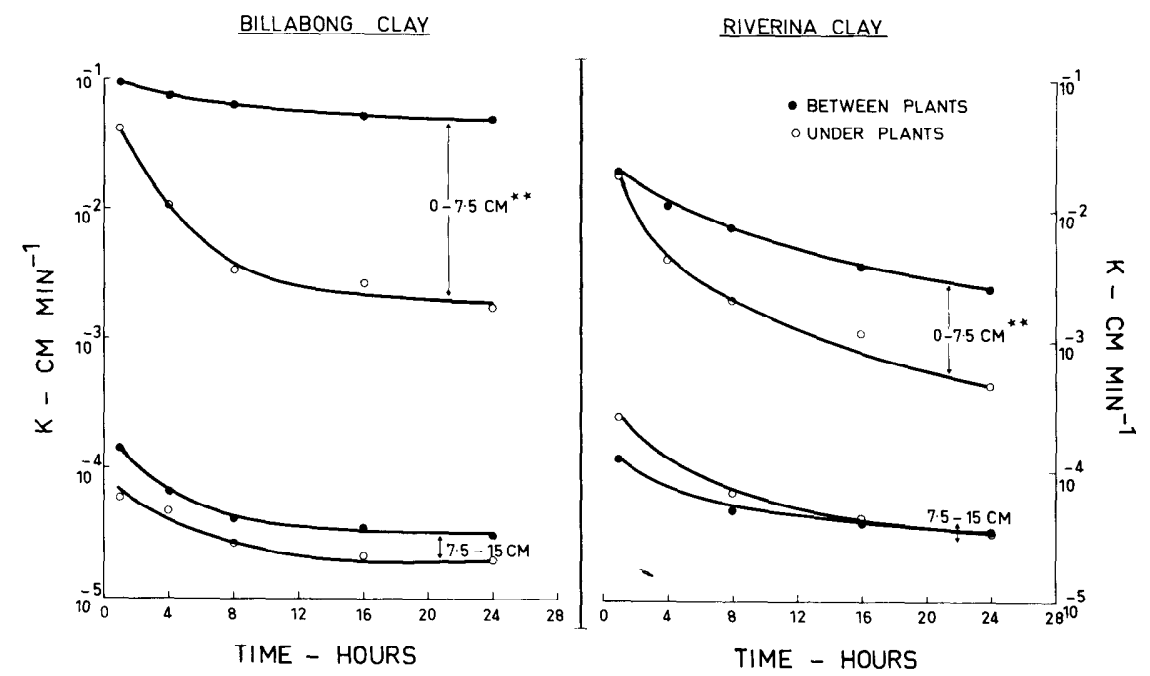

Fig. 3. Mean hydraulic conductivity (K) of 1-2-mm aggregates as a function of time at two depths for Billabong and Riverina clay from between and under the plants of Atriplex nummularia. The statistical significance of difference in hydraulic conductivity (24 hours) for the specified depth is indicated by ${ }^{*}(\mathrm{P}<0.01)$.

illustrate that varying quantities of rain did not significantly affect water penetration and storage between and under the plants of $A$. nummularia. Similarly, gravimetric water contents determined in the profile of Billabong clay before and after several heavy rains $>3.5 \mathrm{~cm}$, so that interception by vegetation was negligible compared to total rain), although not presented here, also confirmed that water penetration and storage in the profile were not affected by the presence of $A$. nummularia. two positions, thus eliminating the possibility of lateral soil particle movement.

Presumably this deterioration of soil structural stability under the plants occurred as a consequence of a significantly larger quantity of exchangeable sodium, as indicated by SAR and ESP values (Tables 1,2$)$. Highly significant negative correlations between ESP and various physical parameters of Billabong clay have been reported earlier (Sharma, 1971). This larger quantity of sodium under plants had accumulated on decomposition of salt-rich leaves and fruits of $A$. nummularia (Sharma and Tongway, 1973). There was also a significant increase in exchangeable $\mathrm{Mg}^{++}$at $U$ compared to $B$ position, which might also be partly responsible for the deterioration of soil structure (van, der Merwe and Burger, 1969).

Factors that would have favoured a better soil structure under $A$. nummularia plants compared to between the plants are increased organic matter and increased electrolyte concentration (Quirk and Schofield, 1955). However, differences in organic matter (Table 3 ) were apparently too small to offset the deleterious effects of exchangeable $\mathrm{Na}^{+}$and probably $\mathrm{Mg}^{++}$ (U.S. Salinity Laboratory Staff, 1954).

It is likely that laboratory evaluation of soil structure by measuring aggregate stability and hydraulic conductivity would have underestimated the effect of electrolytes, since in both methods large quantities of water were used, which would have diluted the effects of electrolytes. Thus, these measurements show mainly the effect of exchangeable cations and would be more appropriate under situations where excessive leaching of soluble salts has occurred.

Since the electrolyte concentration of soil, particularly the surface layer, varies during the year (Sharma and Tongway, 1973), physical parameters evaluated with any single set of electrolyte concentrations would not be applicable under all conditions. The lowest electrolyte concentration occurs after excessive leaching, and the structural differences expected under these conditions are illustrated in Figures 2 and 3 . The structural differences expected under high electrolyte concentrations (when very little or no leaching has occurred) were evaluated by measuring aggregate stability of surface soils in reconstituted electrolyte solutions (made from chloride salts to the same proportions and concentrations of cations as shown in Table 1 for saturation extracts). These average aggregate stability 
values under and between the plants for Billabong clay were 75 and 74 , and for Riverina clay 80 and 82 , respectively. The differences between positions were statistically nonsignificant for both soils. This suggests that deleterious effects on soil structure under the plants due to larger exchangeable $\mathrm{Na}^{+}$would largely be compensated by beneficial effects due to higher electrolyte concentration, provided no excessive leaching has occurred.

In spite of apparent deterioration of soil structural stability (Figs. 2 and 3) under the plants compared to between the plants, field observations showed that water entry and storage in the profile did not significantly differ for the two positions. Under field conditions, it is possible that the suppressing effects on water penetration as a result of structural deterioration due to excessive exchangeable sodium might have been compensated by reduction in soil bulk density and higher electrolyte concentration under the plants. Moreover, significant deterioration in soil structure under plants occurred only in the top 7.5-cm layer, while in the field the hydraulic conductivity of the subsoil is likely to be a limiting factor during water entry. This is clearly indicated in Figure 3 by the fact that at the end of 24 hours, the hydraulic conductivity of the lower depth $(7.5-15 \mathrm{~cm})$ was about two orders of magnitude lower than that of the surface layer $(0-7.5 \mathrm{~cm})$.

It may be difficult to assess the exact contribution of plant-induced soil variability on vegetation distribution and plant growth because of complications caused by simultaneous variations in microenvi-

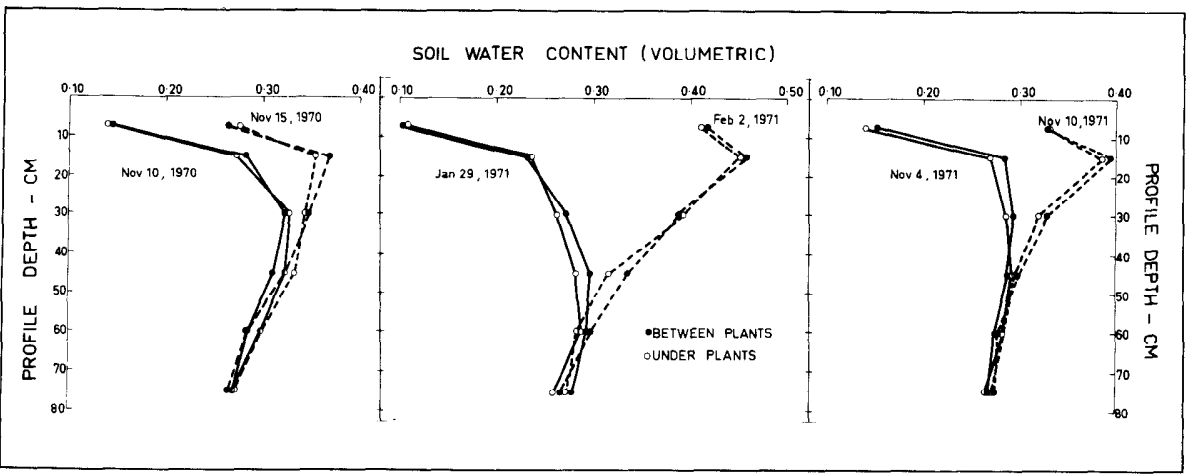

Fig. 4. Soil water profiles of Billabong clay from between and under the plants of Atriplex nummularia. Each point is a mean of seven values as determined by a neutron probe. On all three occasions the differences in increases of soil water between the two positions were statistically nonsignificant at all depths.

ronmental factors. However, it appears that for situations similar to ours, the effects would largely be due to direct salinity and not to variation in soil water properties. This, nevertheless, may not hold for soils with uniform profiles without impermeable subsoil and subject to frequent flooding.

\section{Literature Cited}

Fireman, M., and H. E. Hayward. 1952. Indicator significance of some shrubs in the Escalante desert, Utah. Bot. Gaz. 114:143155.

Jessup, R. W. 1969. Soil salinity in saltbush country of north-eastern South Australia. Trans. Roy. Soc. S. Aust. 93:69-78.

Marshall, T. J. 1956. A plummet balance for measuring the size distribution of soil particles. Aust. J. Appl. Sci. 7:142-147.

Piper, C. S. 1950. Soil and Plant Analysis. The Univ. of Adelaide, Australia.

Quirk, J. P., and R. K. Schofield. 1955. The effects of electrolyte concentration on soil permeability. J. Soil Sci. 6:163-178.

Roberts, E. C. 1950. Chemical effects of salt-tolerant shrubs on soils. Int. Congr. Soil Sci. 4 th. Amsterdam 1:404-406.

Sharma, M. L. 1971. Physical and physicochemical changes in the profile of a sodic soil treated with gypsum. Aust. J. Soil Res. 9:73-82.

Sharma, M. L., and D. J. Tongway. 1973. Plant induced soil salinity patterns in two saltbush (Atriplex spp.) communities. J. Range Manage. 26:121-125.

Stace, H. C. T., G. D. Hubble, R. Brewer, K. H. Northcote, J. R. Sleeman, M. J. Mulcahy, and E. G. Hallsworth. 1968. A Handbook of Australian Soils. Rellim Tech. Publ., Glenside, South Australia.

Tucker, B. M., 1971. Basic exchangeable cations in soils. CSIRO Aust. Div. Soils, Tech. Paper No. 8.

U.S. Salinity Laboratory Staff. 1954. Diagnosis and improvement of saline and alkali soils. U.S. Dep. Agr. Agr. Handbook No. 60.

Van der Merwe, A. J., and R. Burger. 1969. The influence of exchangeable cations on certain physical properties of saline-alkali soils. Agrochemophysica 1:63-66.

\section{On Time Is Right On}

In a recent issue of Rangeman's News, Ronald L. Haag, chairman of the SRM Membership Committee, reported that membership in the Society had increased a whopping $19.2 \%$ in the two-year period ending July 31, 1973-which would seem to indicate that more and more people are becoming more and more concerned about that $40 \%$ plus of the earth's land surface that is rangeland.

Mr. Haag also indicated two principal membership goals: a 95\% renewal by current members for 1974 and a total of at least 5,000 members by the 1974 suspension date. If the proposed revision of the Society's bylaws is approved, this suspension date will be advanced by 60 days, so it is vitally important that your 1974 dues be paid on time-that is, on or before January 1 .

On time is right on-it gives power to the range people! 